Published in: Smith, Claire and H. Martin Wobst. 2005. Wobst (eds.). Indigenous

archaeologies: decolonising theory and practice: 208-225. One World Archaeology 47.

London: Routledge.

\title{
Silencing and Sharing Southern African Indigenous and Embedded Knowledge
}

\author{
Sven Ouzman \\ Anthropology Department \\ 232 Kroeber Hall, University of California at Berkeley, CA 94720-3710, U.S.A. \\ E-mail: ouzman@uclink.berkeley.edu \\ $\&$
}

Rock Art Department, National Museum, PO Box 266, Bloemfontein, 9300, South Africa

\begin{abstract}
Increasingly, more intangible aspects of Indigenous being and heritage are being explored and made known. Though battles over land restitution, the repatriation of people and objects, and related issues are by no means settled, making explicit the systems of thought embedded in these places, people and objects helps overturn stereotypes of Indigenous people as removed from the arena of socio-political action. Fortunately, the last decade has seen unparalleled growth in Indigenous creativity and the empowered transmission of Indigenous knowledge. Indeed, many non-Indigenes are beginning to understand the possibility of a world in which multiple contextually contingent systems of knowledge can operate. Yet willful ignorance persists. In southern Africa Indigenous issues are complicated by c. 2, 000 years of successive human colonisations that have resulted in dangerously ill-defined and shifting terms such as 'African', 'Indigenous' and 'First Nation'. This definitional danger combines with the legacy of Apartheid and a crisis of representation to silence Indigenous knowledge. However, there are encouraging signs that the sharing of Indigenous and Embedded knowledge can act as points of anchorage; re-introducing the potent but eroded role of ritual and storytelling in daily life.
\end{abstract}

\section{The power of words and silences}

Words and silences are powerful things. They hunt together, feeding off each other contrapuntally. The force of a word depends on the quality and texture of the silences surrounding it. Similarly, the valence of a silence is shaped by the words that extend or interrupt it. Words and silences are seldom neutral. Most 
people in southern Africa ${ }^{1}$ know the power of words and silences to exclude. Apartheid $^{2}$ no longer exists officially, but its effects are more than memory (e.g., Lowenberg and Kaempfer 1998). Apartheid took words like 'White', 'nonEuropean', 'Black', 'Coloured' and 'Bushman' and wrought terrible meanings from them. Even a word like 'native' that should denote a prior, Indigenous status was made into a term of such abuse that people avoid it even today. Apartheid identity was measured from a central standard of European-descended whiteness using an impressive array of pseudo-scientific justification (e.g., Dubow 1995). Deviation from this central standard carried a range of penalties some overt such as not being permitted to marry across race or to vote. Other penalties were covert - such as non-Indigenous world-understandings inculcated via Afrikaans and English language education. Southern Africa's First People, the Bushmen $^{3}$ fitted awkwardly into Apartheid's racial classification. Bushmen were considered a primordial people located somewhere between 'nature' and 'culture' (but see Ouzman 2002a). This constructed state of ahistorical, apolitical pristineness permitted both the more familiar forms of racism as well as that paternalistic racism First Nation people know so well (Sylvain 2001). Apartheid's define-and-conquer strategy was dismantled in 1994 with South Africa's first democratic elections. But not only does Apartheid's legacy live on, ingrained in the national psyche, a new and insidious ethnonymy - the practice by which people are named and the authority on which these namings rest (S Hall 1996) is being practiced. The power of words is great but the power of silences is greater. Silences are enemies of memory. I examine two such silences that reside between the words that seek to enclave people, places and objects. I then

\footnotetext{
1 'Southern Africa' comprises the modern geopolities Angola, Botswana, Lesotho, Moçambique, Namibia, South Africa, Swaziland and Zimbabwe.

2 'Apartheid' translates from the Afrikaans as 'separate-ness'. Apartheid was South Africa's National Party's official domestic policy of racial segregation from 1948 - 1994..

${ }^{3}$ The validity of 'Bushman' and 'San' is subject to endless debate. Currently most people prefer to be called by group names like G|ui, Hail|om, Ju|hoansi, ?Khomani, Khwe, !Kung, Naro, Xun and such and as 'Bushman', 'San' or 'Red People' when referred to as a corporate entity (see Hitchcock and Biesele 2000). I like Robert Gordon's articulation of 'Bushman' as a term of nonconformance; of people who refused to acquiesce to the colonial project (Gordon 1992:6).
} 
move on to two instances in which southern Africa can meaningfully share with the world its Indigenous and Embedded knowledge. There is a qualitative difference between 'Indigenous' and 'Embedded' knowledge that needs qualification. 'Indigenous' knowledge is held and developed by a specific autochthonous people, usually long-term residents of a landscape. 'Embedded' knowledge refers also to a landscape-specific fund of knowledge, but one that has been contributed to by a variety of peoples who have lived on that landscape; some of whom may not be Indigenous. The two knowledge systems can be identical; more typically they are two voices in the same conversation; akin to a storyteller and her apprentice.

First Silence: the nature of Indigeneity

By essentialising race, Apartheid de-historicised personhood (M Hall 1999). Only by invoking a biological absoluteness of being and silencing deep-rooted 'nonwhite' claims to the southern African landscape could a white minority government prevail. The silencing of archaeologically verifiable 'non-white' claims took many forms. For example, the putative Phoenician authorship of the 'White Lady' Bushman rock painting in Namibia and the alleged Arabian influence on the Shona-built Great Zimbabwe citadel were popular myths even before Apartheid times (M Hall 1996). Namibian, South African and Rhodesian (now Zimbabwe) history textbooks carried only brief introductions of Bushmen before becoming nationalistic Euro-centric tracts (Smith 1983; Mazel and Stewart 1987). Archaeology and Anthropology were briefly powerful in the early twentieth century (Shepherd 2002), but Apartheid clamped down on them because they demonstrated the long-term residency of southern Africa's 'non-whites'. Moreover, these disciplines did so using scientific techniques such as radiocarbon age determinations and used the logical positivism from which the race project derived its authority to undermine that authority. Now that people can openly debate Apartheid and related policies like imperialism and colonialism, a great debate has arisen as to who is 'Indigenous' and who is not; who belongs in 
Africa and who should go 'home'. Such ethnonomy feeds on the politics of blood. For example, the descendants of Europeans that settled in South Africa's Cape of Good Hope in 1652 have transformed into 'Afrikaners' whose language, identity and allegiance is dominantly shaped by southern Africa. Yet, their apparently non-African blood is argued to exclude them from ever becoming 'Indigenous' southern Africans. What then of southern Africa's other peoples? The c. 30, 000 year history of gatherer-hunter groups ancestral to today's Bushmen is well-known and uncontested (Deacon \& Deacon 1999). Bushman studies are even recognised to be overtly tied to the politics of the day (e.g., Lewis-Williams 1995). But there are two other macro cultural groups whose status has shifted from 'immigrants' to 'indigenes'.

Approximately 2, 000 years ago, the presence of Khoe-speaking ${ }^{4}$ herder peoples in southern Africa is detected via artefacts, genetics and language (Boonzaier et al. 1996). Though academics argue the validity and inter-relationships of 'Bushman' and 'Khoe' (Reid et al. 1998), there is no denying a deep Khoe ancestral presence. At the same time, 'black' Bantu-speaking farmers also moved into southern Africa from central Africa's Great Lakes region (Ehret 1998). These two groups, together with Bushmen and later Europeans, interacted and new identity formations resulted and continue to be formed. But unlike Afrikaners; Khoe and Bantu-speakers are considered Indigenous both by virtue of an African bloodline and by length of residence. This latter criterion mirrors the 'man with a beard' argument in which everyone has a different notion of when, exactly, a man has a beard. Is one hair on a man's face enough? Two? A Hundred? More? Similarly, how long must one be a resident to be considered native? Only the churlish would quibble that 2, 000 years is insufficient residency to qualify at least as a 'local'. But is 'local' a necessary and sufficient condition of indigeneity? Definitions of 'Indigenous' abound (e.g., International Labour Organization 1989), sharing notions of a long-term community embedded in a landscape. To this 
definition is often added some notion of inequality with other, usually nonIndigenous groups. This latter notion was true during Apartheid, but since 1994 previously marginalised Bantu-speakers are dominant as the elected government. Theirs is a very particular emancipation, however, as the status and claims of other Indigenous groups are masked by corporate nationhood. The best example of such masking is South Africa's language policy. In the interests of nation-building, it was decided to have eleven official languages. This policy helped counter the hegemony of Afrikaans and English and empowered many speech communities by weaving their words into the national fabric. Yet the official languages are either European (Afrikaans and English) or Bantu (isiNdebele, isiXhosa, isiZulu, Sepedi, Sesotho, Setswana, siSwati, Tshivenda and Xitsonga,). No Bushman or Khoe language is represented. The Pan South African Language Board was mandated to investigate Nama, a Khoe language, as a twelfth national language, but this investigation is over a decade old (Webb 2002). Even well-intentioned initiatives aimed at promoting a national identity come at the price of marginalising those people who least easily fit into corporate concepts of nationhood. The result is a silencing of First Voices by oversight.

Bushman identity seldom meshes with the nationalisms that developed after first contact. Though early contact was cordial and certain farmers even paid first rites tributes to Bushmen in acknowledgement of their prior custodianship of the land, latterly matters have deteriorated. Botswana is the most extreme example of Bushmen as a sublimated nation (Gall 2001). The distinct and irrefutable First Nation status of the Bushmen in Botswana undermines the political authority of a government and nation state made up of more recent arrivals (Saugestad 1998). So a policy of assimilation has been initiated with Bushmen encouraged financially and by force to speak Setswana, send their children to Tswana schools and adopt a Tswana lifestyle. The situation is difficult as Bushmen no longer live as gatherer-hunters able to vote with their feet - they have not lived

\footnotetext{
${ }^{4}$ Like 'Bushman', the ethonym 'Khoe' is vigorously debated. The Khoe are also known as 'Khoi', 'Khoikhoi', 'Khoekhoen' and the derogatory 'Hottentot' (see Smith 1998). Under Apartheid, many
} 
like this for some decades now - and they retain a custodial rather than hegemonic ethos to land, people and property. These factors tempt nonBushman to create a Bushman supra-nationalism not tied to citizenship. This ploy fails as it removes Bushmen from a national body politic (Suzman 2001), allowing Bushmen to be assimilated as a landless underclass (Gordon 1992). An insightful example of the relationship between personhood and citizenship is the repatriation of 'El Negro'. This account begins in 1830 when Edouard and Jules Verreaux stole a just-buried body buried in northern South Africa, just south of what is now Botswana (Parsons 2002; Segobye 2002). The brothers stuffed this man's body and took their 'trophy' to France. In 1880, after the brother's deaths, the stuffed Motswana was bought by naturalist Francesc Darder. Darder later bequeathed his collection including the grisly 'trophy' to Banyoles in northern Spain to be displayed in the Museo Darder, which opened in 1916 (ibid). The body, known as 'El Negro', remained on display until 1991 when an Haitian doctor caused an outcry over this insensitive practice. After much publicity and resistance from both Spain and Botswana, El Negro was repatriated to Botswana on 5 October 2000. One of the reasons for resistance was El Negro's identity. Initially El Negro was thought to be 'Bushman' - an identification with little political mileage within Botswana (Good 2002). Another reason for repatriation resistance was the South African origin of El Negro. Until 1994 Botswana was a 'frontline state' against Apartheid South Africa and resistant to things South African. However, the Tswana-ness of El Negro was considered prior to any South African identity. 'Botswana', after all, translates as 'place' or 'home' of the Tswana. Rather than use El Negro to build a broader concept of Botswana nationhood narrow nationalism intervened - though not without critique (Gewald 2002). Though southern Africa has Bushman, Khoe and Bantu indigenous peoples only Bushmen can claim First Nation status. To call oneself 'Indigenous' is accurate - but it is only accurate and true if mentioned in relation to First Nationhood.

Khoe-descended people were designated 'coloured'. 
Second Silence: the Rainbow Nation - celebrating diversity?

Seldom, however, do people qualify their status thus; conflating 'Indigenous' and 'First Nation' in a knotty nexus of personal, group, national and regional identity. A recent difference of opinion has brought to general consciousness how entangled the South Africa cultural mosaic really is. Given the uncertain nature of South African society at the 1994 elections, Anglican Archbishop Desmond Tutu, borrowing from Jesse Jackson's 1988 'rainbow coalition', coined the term 'Rainbow Nation' to celebrate South Africa's cultural diversity and to defuse racial, ethnic and class tensions at a time when promise and peril intersected (Trengrove-Jones 1999). Battle-weary South Africans craving a sense of nationhood adopted this term to the extent that the seemingly impossible became conceivable. Rugby, traditionally a white supremacist sport, was the first test case of national solidarity when, a year after elections, South Africa hosted the Rugby World Cup. Amazingly, South Africa won the competition and enjoyed broad national support. The victory and support seemed a sign of a higher power approving our rainbowness (see Coetzee 1995). The stage seemed set for miraculous possibilities. Soon any awkward cross-cultural divide could be bridged by rainbow-speak. But Umberto Eco warns that overuse of words and metaphors makes them meaningless (Eco 1995). Overuse also masks subaltern voices. While good to be a member of the 'Rainbow Nation', citizens must take care that they do not support a project in which an Apartheid-era stereotype of separate constructed identities is replaced with an homogenous inclusivity that sanctions a dominant group's identity and voice (Alexander 1997; Fig 1). Nationhood consists both of knowing who one is and who one is not. A cogent critique of the Rainbow Nation concept - an uneasy mix of multi-culturalism and the melting pot - has come from one of southern Africa's Indigenous peoples.

People called 'coloured' and who spoke the language and practiced many of the customs of their Afrikaans oppressors (Goldin 1987), vented their frustration at previously not being white enough under Apartheid (Fig. 2) and now not being black enough in democratic times. Their dilemma was encapsulated in the 
ethonym 'coloured' - a term designating a people created by miscegenation between prior 'black' and 'white' people. However 'coloured' people's southern African roots extend back at least 2, 000 years to the arrival of Khoe-speaking herder peoples. Yet even 2, 000 years' pedigree is only partially helpful because Bantu-speaking farmers ancestral to the various 'black' groups resident in and governing southern Africa also arrived at about this time. Both groups thus have an equally valid time-depth based claim on the landscape. But elections have tilted the balance and democratically validated a black overlord status. To counter this hegemony the 'Khoisan Identities and Cultural Heritage' was held in Cape Town in 1997. Academics and activists participated with Bushman, Khoe and other Indigenous groups in robustly discussing identity and heritage (Bank 1997). This finding of a voice led to the compound ethonym 'Khoisan' being adopted to convey a reclaiming of Indigenous identity and heritage. After all, the term 'Khoisan' had currency within academia, why not also in wider society?

The reason why not is vigorously argued by most Bushmen (e.g., WIMSA 2001). They argue that after 2, 000 years Khoe and Bushman had become enmeshed but not to the degree of sharing a common identity and heritage. Part of the problem is demographic. Most of the 100000 plus Bushmen live in Angola, Botswana and Namibia, with less than 8000 Bushmen resident in South Africa where Khoe/coloured people are most populous. Even Bushmen resident in South Africa - notably the !Xun and Khwe - moved there from Angola on invitation of the Apartheid government for whom they had worked as trackers in the Angola - South Africa war. In a supreme twist of fate the !Xun and Khwe did not until 1998 get South African citizenship and were for years refugees in their ancestor's land. Fortunately, they have posited an articulate presence backed up by innovative actions such as asserting custodianship of the Wildebeestkuil Bushman rock art site now developed for tourism and use as a heritage center (www.museumsnc.co.za/wildebeestkuil). Similar successes such as the Hoodia biopiracy case (Geingos and Ngakaeaja 2002), and 52000 hectare Khomani land repatriation (Chennells 2002) are more common, and Bushman voices are 
less easily silenced. They object to their 30, 000 year 'First Nation' history being co-opted by more recent arrivals (Suzman 2001 for perils of ancestry-based First Nation claims). Just how modular and fragile the 'Khoe-San' ethonym can be is shown by the celebrated case of Sara Baartman.

Briefly (see Abrahams 1998 for a fuller account and Maseko 1998 for a video rendition), Sara Baartman (we do not know her true name) was born in 1788 or 1789 (ironically, the year of the French Revolution) at Hankey in the Eastern Cape Province of South Africa. Married and a mother, Sara was soon denied both statuses and she attempted to escape the discrimination of the Dutch and British colonists. Trading on a European imaginary of Africa as the continent of the exotic and shocking, Sara entered into an agreement with Hendrik Cezar to tour European freak shows (see Thompson 1996) between 1810 and 1815. In France Sara was received with acclaim because of the voyeuristic continental fantasy of the 'Hottentot apron' or exaggerated labia minora of Indigenous southern African women (Fig. 3). Sara died in Paris in 1816. With indecent haste the anatomist Cuvier preserved her spine, brains and sexual organs. Sara's remains were displayed in the Museé de l'Homme and then consigned to storage. But people remembered this cause celebre and slowly pressure mounted for her repatriation, which came to pass on 10 August 2002 (Tau 2002). Tellingly, Sara Baartman was almost always referred to as 'Khoe' - the alliance with the 'San' suspended.

\section{The power of sharing Indigenous and Embedded knowledge}

Fortunately, not all inter-cultural alliances are contested or restricted to the past. For example, the renown Bushmen enjoy as trackers - an activity used to support stereotypes of Bushmen 'one-ness with nature' - can also interface seamlessly with Western technology. Louis Liebenberg, a non-Bushman tracker and activist, in consultation with Bushman trackers employed by the South African National Parks, developed a global positioning system (GPS) that uses visual icons that Bushman trackers - who cannot read text but who are masters 
of reading sign - could press whenever they saw physical evidence of the animal represented by the icon (Bailey 1997). The GPS would then supply a contextualised co-ordinate that aided more effective parks management. In ways such as this, the practice of 'smash-and-grab' research by non-Indigenous people prospecting communities and leaving little behind, is giving way to a more sensitised and even contractual way of working (Smith 1999; Hitchcock 2002).

So Indigenous people teach researchers not just new knowledge but the possibility of new ways of knowing (Ouzman 1999). This optimism must be tempered by realising that acquiring knowledge is not a value-free, inevitable pursuit (e.g., Turnbull 2000). Knowledge can be specific and exclusive. It may even harm the seeker. Knowing when to keep silent can create the necessary conditions for sharing knowledge by demonstrating respect for the contexts in which Indigenous and Embedded knowledge exist. In other words, people need to know where they have come from, where they think they want to go and the means by which they think that they might get there. This search for identity and roots is not peculiar to the 'Rainbow Nation', (Gupta and Ferguson 1997) but South Africa's uniquely positioned and robustly questioning search for roots and future and experience from a global periphery can offer the rest of the world guidance (c.f. Hodgson 2002). I now posit two possibilities for sharing.

First Sharing: Africa as humanity's home

In terms of evolutionary theory, southern and East Africa are humanity's Alpha points - the landscapes from which all ancient and modern humans originated (Deacon and Deacon 1999: 10-25). Far from being a 'Third' world of dependence and malaise, Africa is in a very real sense the 'First' world and offers to people who feel displaced and rootless the knowledge of an ultimate human home. It was from this African originary that first great Diaspora began (Cavalli-Sforza et al 1996). Indeed, the Africa Union should perhaps levy an Origin Tax on the 'First' world, which would not have existed were it not for Africa (Ouzman 2002b). To 'First Nation', the notion of 'Origin Nation' identity emerges. Fortunately, this 
is an identity all people can share; even those Afrikaners latterly returned to Africa after a European sojourn. But sharing roots can come at the cost of associating Africa only with ancient and inevitable evolutionary processes. This reasoning has it that cultural modernity only developed once humans arrived in Europe. Even when Europe recognised African achievements like the Africaninspired Primitivist art movement; the African component was characterised as 'vital' rather than 'intellectual'. Fortunately, signatures of cultural modernity such as 'art' may be claimed as African inventions; though art is likely also to have had later independent inventions in non-African places. Empirical proof of an African art origin are two intentionally decorated ochre pieces recovered from Blombos Cave in South Africa in archaeological layers $\sim 70,000$ years old (Whitehouse 2002; Fig. 4). This is twice as old as any comparable 'art' out of Africa. Indeed, southern Africa has more ochre implicated in symbolic contexts than anywhere else that combine with the richness of our rock art heritages to make 'Africa' and 'Art' almost synonymous. Again, this precocious modernity should not place African innovation only in the past. Blues and rock music may are also dominantly African, having developed out of African slaves' songs of lament, celebration and resistance when abducted to the New World. Cultural appropriation is not always a bad thing if honour is done to the originator community. Reversing the process, Ndebele Bantu-speaker's architecture (Fig. 5) blends distinctive 'Cape Dutch' European architecture with indigenous Ndebele forms. This result is an acceptable African idiom that does no violence to the source of the copy or raise objections from its originators.

Second Sharing: the need for ritual, contemplation and storytelling The dialogue between people, places and objects may be extended to address the alienation and rootlessness many people experience in the face of 'globalisation'. The need for uniformity and compatibility between systems, people and nations and the porosity of national and personal boundaries has both eroded local textures, customs and knowings and promoted them (e.g., Foster 1991; Watson 1997). People seeking to counter uniformity wish to ground- 
truth their identity in aspects of their personhood and past. The re-invigoration of concepts like Bantu-speaker's 'ubuntu' where the message hails that we all have something to learn from and teach each other (Mbigi 1995), challenges notions of what is 'dominant' and what is 'subaltern'. More intimately, many people no longer mark important life passages with appropriate rituals. These unceremonious people are offered the possibility of learning about responsibility, respect and reciprocity from embedded Indigenous rituals. For example, traditional southern African Indigenous boy's and girl's initiation rituals were and are intended to inculcate deep societal and behavioural norms about self and responsibility into youths on the cusp of adulthood. 'Traditional' is a difficult concept and one that does not denote something backward or unchanging. Rather 'tradition' means those beliefs and practices that are consciously cast in opposition to colonialism, globalisation and the like (Sharp 1988). 'Tradition' creates the conditions of possibility for cultural innovation (Anderson 1991); an Indigenous way of keeping ahead of and managing cultural change. Sometimes we may use mutual and innovative instances of cultural appropriation such as the South African version of the children's educational television programme Sesame Street becoming the first franchise to have a character that is HIV-positive (Deans 2002). This adaptation of a powerful concept-forming 'Western' medium to a local circumstance shows an intelligent use of available global resources grounded in traditional values and addressing a contemporary problem. Such usages help shake people out of their 'perpetual state of partial attention'. Deep thinkers' ranks have become thinned and public opinion is swayed by powerful cliques with access to the means by which knowledge is transmitted, leading to sterile thinking (Friedman 2001). One of the few places at which innovative, relevant thought is being produced is the Indigenous 'Fourth World' (Young 1995), where the centrality of a place and its stories has always featured strongly.

So much of a person's identity is locational - you are where you are - that visiting the places where one was born, grew up and experienced important events is a 
ritual that needs to be promoted (Dladla and Schutze 2002). The true violence of Apartheid is the geographical dislocation that precipitated a crisis of identity. The ancient African and human tradition of storytelling has great emancipatory potential. The word 'story' is understood to denote a whimsical non-truth, fiction, fable or legend. But 'story' is also being reclaimed to mean a robust narrative borne out of a certain soil and people; allowing people to talk about themselves and the world in ways dear and enduring to them (Hinchman and Hinchman 1997). Often, these stories have a wider application from which all people can learn and take inspiration. Allow me to tell such a story dear to me. In 1995 I was faced with a conundrum. I was in Zimbabwe on the tenth Congress of the Pan African Association for Prehistory and Related Studies' field trip. The excursion had unexpectedly been paid for by a miserly employer thanks to strategies that do not here bear repeating. I had to choose between watching the rugby World Cup final and going to the famous Bambata Cave. Shallowness won out and Lloyd Rousseau and I elbowed our way into a Bulawayo bar, five minutes after kickoff. For the next hundred minutes we were captured by a ding-dong game that had all the whites in the bar cheering and beering. After a while I noticed a lone black man also cheering. Intrigued, I sat next to him and we started talking. His name was Jonathan and he was in Zimbabwe selling bark cloth from Burkino Fasso. Previously Upper Volta, his country had declared war on Apartheid South Africa in 1981 and only rescinded this status in the late 1990s. I asked Jonathan straight out how he could support a near all-white South African rugby team? His answer was a simple clarity. "Because", he said, "they are an African team". Ironically, the other team in the final was the New Zealand All Blacks ${ }^{5}$. The simple time spent telling a story that ended by Jonathan putting my world into clearer perspective, is one that helped shape my understanding of Archaeology and Anthropology as adventures in storytelling (see Joyce 2002).

\footnotetext{
${ }^{5}$ The name 'All Blacks' is the result of a printer's error. The legendary 1905 New Zealand rugby team had such mobile forward players that one news reporter wrote that the team played as though they were 'all backs', meaning that the forwards were as fast and skilled as the backline players. A printer's error, made `all backs' into ‘all blacks' and the name stuck
} 
This realisation has many implications, not the least of which is that the tools of the Academy seldom transfer to others the wonder of place, person and history. Storytelling does not embargo publishing theoretically dense articles (e.g., Nuttall and Coetzee 2000). Rather, such academic ventures should be accompanied by more accessible and experiential tropes (see Pluciennik 1999) such as video and visiting sites. Australian archaeologists have produced 'plain English' reports using the Creole used by the Aboriginal communities in which they work. Unlike text storytelling is accessible to virtually everyone. Storytelling lets people and landscapes know you hold them in memory and perpetuate them in the telling. When people find themselves in unfamiliar surroundings or when previously familiar places become alien because of violence and the failure of memory, stories help people cope. Stories are also gateways to virtuosity. In contrast to the Foucaultian notion that people are subjugated by the imposition of a constant, repetitive and demeaning routine (Foucault 1977); the repetitiveness of storytelling permits liberation. We applaud artists, composers and authors because the genius of their work lies in the constant iteration of the play of light \& shadow; notes \& pauses; words \& silences. Repetition leads to perfection. And so it is with storytelling; a craft that allows for the suspension of disbelief; the coexistence of past and present and an almost infinite imagination of human existence. Consider the /Xam Bushmen. They no longer exist nor is /Xam spoken today. Yet the /Xam were virtuoso storytellers who lived in the central interior of South Africa and whose narratives have helped shaped modern South Africa. Devastated by colonial disease and violence, the /Xam wished their stories to live on because they knew they would not. In the 1870s they related in aspects of their history, customs, being, belief and more to the German linguist Wilhelm Bleek and his co-workers Lucy Lloyd and Dorothea Bleek (Deacon and Dowson 1996; Lewis-Williams 2001). Though literally prisoners, 14 /Xam storytellers have given us a glimpse of a first literature. Their stories were written down as spoken and retain an elliptical nature that speaks of the savour that comes when a story is told and re-told properly; when words and pauses are in the proper balance, maintaining an essential tension. We are doubly fortunate in that photographs 
and portraits and personal notes were taken of these /Xam women and men (Fig. 6) so that word and image powerfully co-exist. /Xam virtuosity is not forgotten. On 27 April 2000 South Africa's new coat of arms was unveiled bearing the /Xam motto !Ke e: /Xarra //Ke - 'In diversity strength' (Fig. 7; Smith et al. 2000) playing on the previous 'In unity strength'. So South Africa's past catches up with its present. We love the sound of our voices; or maybe it is the communal nature of storytelling that enables what Victor Turner so elegantly described as 'communitas' (Turner 1974) that draws us to this activity. The performance of speaking, a most embodied experience (Bakhtin 1981), offers powerful ways of sharing core human experience.

\section{Conclusion - back to the beginning}

A similar human activity is talking about where we are going. But this makes no sense unless we know where we come from. Telling multiple origin narratives locates evolution as but one of a range one of culturally specific origin stories. All people are placed on an equal footing, at a point of mutual comprehension. Origin stories blend history, landscape and being in similar and provocatively different ways (e.g. Walker 1997); encouraging conversation. If these conversations could be held at or near the physical origin sites, more of the story's power is unlocked. Yet even this sharing of stories carries a baggage of silences. Not everyone is permitted to speak as Indigenous voices often challenge more recent nationalistic identity formations. Also, not everyone is prepared to listen. People need to acquire listening skills and the ability to evaluate stories. Sometimes a skilful storyteller may tell beguiling but false stories (Briggs 1996; Jones 2001). Nicholas David pithily observed that: "Archaeology's primary role is not, after all, that of a purveyor of satisfying pasts and identities to ethnic, national and social groups" (David 1984). I recall my high school history teacher, the late and lamented Tony Vorster, telling his bright and bewildered class that "History has many sides and many stories; only one of which I am today permitted to tell you". This curious sentence, with those unvoiced histories alluded to, tweaked in me some small but fundamental re- 
alignment that charted for me an entirely different path than that I was on. Silence and sharing exist in a relation of musical counterpoint - but not always an harmonious one. Just as Archaeology is not in the business of purveying satisfying pasts so Indigenous and Embedded knowledge should seek not only to create accommodating spaces but also to make people uncomfortable and aware of the violence and contestation that continues still today. The task at hand remains impossibly large. It is important that everyone is allowed to speak; whether they will be listened to depends largely on their storytelling skill. People need to be made aware of the co-existence of different knowledge systems and how they bed in particular landscapes and people as well as in the global ecumene. We have in this regard a responsibility to use and share with the world our Indigenous and Embedded knowledge and so become agents of questioning, compassion and radiance.

\section{Acknowledgements}

I thank Magdalena Brörmann, Axel Thoma and Joram Useb of the Working Group of Indigenous Minorities in Southern Africa (WIMSA); Roger Chennels, Kathy Dowdall, Kathryn Mathers and James Suzman; and Mario Mahongo and Hennie Swart of the !Xun and Khwe Communal Property Association for their comments and Donald Moore for many stimulating thoughts. Tracey Treloar has shown much patience with this manuscript. I thank Chris Henshilwood for permission to reproduce Figure 4 and 'Ora Joubert for Figure 5. I thank Claire Smith and Martin Wobst for choosing me as their first author of last resort.

\section{Bibliography}

Abrahams, Y. (1998) 'Images of Sara Baartman: sexuality, race, and gender', in W. Roach-Pierson and Chauduri, N. (eds), Nation, empire, colony: historicising gender and race: 220-36, Bloomington (IN): Indiana University Press.

Alexander, J. (1997) 'Colours of the rainbow do not necessarily mix well', Cape Argus, 23 October.

Anderson, B. (1991) Imagined communities: reflections on the origin and spread of nationalism, London: Verso. 
Bailey, K. (1997) 'Stone age skills meet the challenge of the techno age', The Times, 8 October.

Bank, L. (ed.) (1997) The proceedings of the Khoisan Identities and cultural heritage conference. Cape Town: The Institute for Historical Research, University of the Western Cape.

Bakhtin, M. (1981) The dialogic imagination: four essays, Austin (TX): University of Texas Press.

Boonzaier, E., Malherbe, C. and Smith, A. (1996) The Cape herders: a history of the Khoikhoi of southern Africa, Cape Town: David Philip.

Briggs, C. (ed.) (1996) Disorderly discourse: narrative, conflict and inequality, New York: Oxford University Press.

Cavalli-Sforza, L.L., Cavalli-Sforza, F., Thorne, S. and Mimnaugh, H. (1996) The great human diasporas: the history of diversity and evolution, Cambridge (MA): Perseus Press.

Chennels, R. 'Traditional knowledge and intellectual property', paper presented at the $25^{\text {th }}$ International Bar Association conference, 20-25 October 2002.

Coetzee, J.M. (1995) 'Retrospect: the World Cup of rugby', South African Review of Books, 38: 20-21.

David, N. (1984) Editorial, African Archaeological Review, 2: 1-3.

Deacon, H.J. and Deacon, J. (1999) Human beginnings in South Africa: uncovering the secrets of the Stone Age, Cape Town: David Philip.

Deacon, J. and Dowson, T.A. (eds) (1996) Voices from the past: the /Xam Bushmen and the Bleek and Lloyd collection, Johannesburg: Witwatersrand University Press.

Deans, J. (2002) 'HIV-positive vibes on Sesame Street', Guardian Unlimited, July $12 . \quad$ Online. Available http://media.guardian.co.uk/broadcast/story/0,7493,754228,00.html. (accessed 1 August 2002).

Dladla, S. and Schutze, E. (2002) 'Place of the ancestors', Land and Rural Digest, May/June: 19-24.

Dubow, S. (1995) Scientific racism in modern South Africa, Cambridge: Cambridge University Press. 
Ehret, C. (1998) An African classical age: eastern and southern Africa in world history, 1000 BC to AD 400, Oxford: James Currey.

Eco, U. (1995) Faith in fakes: travels in hyper reality, London: Secker \& Warburg.

Foster, R. J. (1991), 'Making global cultures in the global ecumene', Annual Review of Anthropology, 20: 235-60.

Foucault, M. (1977) Discipline and punish, London: Allen Lane.

Friedman, J. (2001) 'From roots to routes: tropes for trippers', Anthropological Theory 2 (1): 21-36.

Gall, S. (2001) Bushmen of South Africa: slaughter of the innocent, Johannesburg: Random House.

Geingos, V. and Ngakaeaja, M 'Traditional knowledge of the San in southern Africa: Hoodia gordonia', paper presented at Biopiracy - then years post Rio $2^{\text {nd }}$ South-South Biopiracy summit, Johannesburg, South Africa, 22-23 August 2002.

Gewald, J-B. (2002) 'El Negro, el Niño, witchcraft and the absence of rain', Pula: Botswana Journal of African Studies, 16 (1): 37-51

Goldin, I. (1987) Making race : the politics and economics of Coloured identity in South Africa, Cape Town: Maskew Miller Longman.

Good, K. (2002) 'The only good Bushman...', Pula: Botswana Journal of African Studies, 16(1): 52-56.

Gordon, R. (1992) The Bushman myth: the making of a Namibian underclass, Boulder (CO): Westview Press.

Gupta, A. and Ferguson, J. (eds) (1997) Culture, power, place: explorations in critical Anthropology, Durham (NC): Duke University Press.

Hall, M. (1996) Archaeology Africa, Cape Town: David Philip.

Hall, M. (1999) 'Subaltern voices? Finding the spaces between things and words', in P.P.A. Funari, M. Hall and Jones, S. (eds) Historical archaeology back from the edge: 193-203, London: Routledge.

Hall, S. (1996) Questions of cultural identity, London: Sage.

Hinchman, L. and S. Hinchman. (eds) (1997) Memory, identity, community :the idea of narrative in the Human Sciences, Albany (NY): State University of New York Press. 
Hitchcock, R.K. (2002) 'Repatriation, indigenous peoples, and developments lessons from Africa, North America and Australia', Pula: Botswana Journal of African Studies, 16(1): 57-67.

Hitchcock, R.K. and Biesele, M. (2000) 'San, Khwe, Basarwa, or Bushmen? Terminology, identity, and empowerment in southern Africa' Online. Available http:www.kalahari.peoples.org/san-term.htm (accessed 4 August 2002).

Hodgson, D.I. (2002) 'Introduction: comparative perspectives on the indigenous rights movement in Africa and in the Americas', American Anthropologist 104(4) 1037-47.

International Labour Organisation (1989) Convention 169: convention concerning Indigenous and Tribal peoples in independent countries, Geneva.

Ismael, A. (1998) 'Victory as Griqua gain first nation status', The Sunday Times 9 August.

Jones, J.D.F. (2001) Storyteller: the many lives of Laurens van der Post, London: John Murray.

Joyce, R. (2002) The languages of Archaeology: dialogue, narrative, and writing, Oxford: Blackwell Publishing.

Lewis-Williams, J.D. (1995) 'Some aspects of rock art research in the politics of present-day South Africa', in K. Helskog and Olsen, B. (eds) Perceiving rock art: social and political perspectives: 317-37, Oslo: Novus Forlag.

Lewis-Williams, J.D. (2001) Stories that float from afar: folklore of the /Xam Bushmen, Cape Town: David Philip.

Lowenberg, A.D. and Kaempfer, W.H. (1998) The origins and demise of South African Apartheid: a public choice analysis, Ann Arbor (MI): University of Michigan Press.

Maseko, Z. (1998) The life and times of Sara Baartman: the Hottentot Venus, Film, First Run/lcarus Films.

Mazel, A.D. and Stewart, P.M. (1987) 'Meddling with the mind: the treatment of San hunter-gatherers and the origins of South Africa's black population in recent South African school history textbooks', South African Archaeological Bulletin, 42: 166-70.

Mbigi, L. (1995) Ubuntu: a rainbow celebration of cultural diversity, Pretoria: Ubuntu School of Philosophy. 
Nuttall, S. and Coetzee, C. (eds) (2000). Negotiating the past: the making of memory in South Africa, Cape Town: Oxford University Press.

Ouzman, S. (1999) 'Guest editorial: Indigenous intellectual property rights', Southern African Field Archaeology, 8: 57-9.

Ouzman, S. (2002a) 'Encountering an encultured nature: some edifying examples from Indigenous southern Africa', in Gauer-Lietz, S. (ed.) Nature and culture: ambivalent dimensions: 199-217, Cottbus: Drukzone.

Ouzman, S. (2002b) 'Origin Tax? Render unto Africans what is rightly ours', The Sunday Independent, 14 July.

Parsons, N. (2002) 'One body playing many parts - le Betjouana, el Negro and il Bosquimano', Pula: Botswana Journal of African Studies, 16(1): 19-29.

Pluciennik, M. (1999) 'Archaeological narratives and other ways of telling', Current Anthropology, 40(5): 653-78.

Reid, A., Sadr, K. and Hanson-James, N. (1998) 'Herding traditions', in P. Lane, A. Reid, and Segobye, A (eds) Ditswa Mmung: the archaeology of Botswana: 81100, Gaborone: Pula Press and the Botswana Society.

Saugestad, S. (1998) The inconvenient Indigenous: remote area development in Botswana, donor assistance, and the First People of the Kalahari, Tromso: Faculty of Social Science, University of Norway.

Segobye, A. (2002) 'Missing persons, stolen bodies and issues of patrimony: the El Negro story', Pula: Botswana Journal of African Studies, 16(1): 14-18.

Sharp, J. (1988) 'Introduction' in E. Boonzaier and Sharp, J. (eds) South African Keywords: the uses and abuses of political concepts, Cape Town: David Philip.

Shepherd, N.J. (2002) 'Disciplining Archaeology, the invention of South African prehistory, 1923-1953', Kronos.

Smith, A.B. (1983) 'The Hotnot syndrome: myth-making in South African school textbooks', Social Dynamics, 9(2): 37-49.

Smith, A.B. (1998) 'Khoesaan orthography', The South African Archaeological Bulletin, 53: 37-8.

Smith, B.W., Lewis-Williams, J.D., Blundell, G. and Chippindale, C. (2000) 'Archaeology and symbolism in the new South African coat of arms', Antiquity, 74: 467-68. 
Suzman, J. (2001) Indigenous wrongs and human rights: national policy, international resolutions and the status of the San in southern Africa', in A. Barnard and Kenrick, J. (eds) Africa's indigenous minorities, Edinburgh: African Studies Centre.

Sylvain, R. (2001) 'Bushmen, Boers and baasskap: patriarchy and paternalism on Afrikaner farms in the Omaheke region, Namibia', Journal of Southern African Studies, 21(4): 717-37.

Tau, M. (2002) 'Sarah Baartman to be buried in Eastern Cape', BuaNews, 5 July.

Thompson, R.G. (ed) (1996) Freakery: cultural spectacles of the extraordinary body, New York: New York University Press.

Trengrove-Jones, T. (1999) 'In search of a heritage for our fragmented nation', The Sunday Times, 19 December.

Tuhiwa-Smith, L. (1999) Decolonizing methodologies: research and indigenous peoples, London: Zed Books.

Turnbull, D. (2000) Masons, tricksters and cartographers: comparative studies in the sociology of scientific and indigenous knowledge, Amsterdam: Harwood Academic Publishers.

Turner, V.W. (1974) 'Pilgrimage and Communitas', Studia Missionalia, 23: 30527

Walker, N. (1997) 'In the footsteps of the ancestors: the Matsieng creation site in Botswana', The South African Archaeological Bulletin, 52: 95-104.

Watson, I. (1997) 'Indigenous people's law-ways: survival against the colonial state', Australian Feminist Law Journal, 8: 39-58.

Webb, V.N. (2002) 'Language policy in post-Apartheid South Africa', in J.W. Tollofson and Tsui, A.M.B. (eds) Medium of instruction policies: which agenda? Whose agenda?, Mahaw (NJ): Lawrence Earlbaum Associates.

Whitehouse, D. (2002) 'Oldest' prehistoric art found: are abstract markings on piece of ochre ancient art?', BBC News. Online. Available http://news.bbc.co.uk/1/hi/sci/tech/1753326.stm (accessed 4 October 2002).

Wildebeestkuil rock art site http://www.museumsnc.co.za/images/wildebeestkuil, (accessed $12^{\text {th }}$ January). 
WIMSA. (2001) The Penduka Declaration on the standardisation of Ju and Khoe languages, Windhoek, 20-22 April.

Young, E. (1995) Third World in the First: development and indigenous peoples, London: Routledge.

\section{List of figures}

Figure 1: Zapiro cartoon. (c) and courtesy of Jonathan Shapiro.

Figure 2: c. 1999 CE graffiti from Muzenburg Cape Town, South Africa alluding to Apartheid's 'define-and-conquer' governmentality - "Stay/Remain a Hottentot Vote NP [National Party]". Image courtesy of Penny Berens.

Figure 3: Nineteenth century entitled Les Curieux en extase ou les cordons de souliers, c. 1812 satirising French perversity and fascination with a sexual African imaginary personified by Sara Baartman, the 'Hottentot Venus'. Exclamations include: "Oh! God Damn what roast beef!" and "Ah! how comical is nature". Original in Bibliotheque National, Paris.

Figure 4: One of two intentionally decorated ochre pieces from Blombos Cave, South Africa, c. 77000 years old. Image courtesy of Chris Henshilwood.

Figure 5: Ndebele architecture - an Indigenous southern African appropriation of European architecture blended with local forms.

Figure 6: Portrait of //Kabbo - 'Dream' - master /Xam storyteller. Chromalithographic frontispiece from Bleek, W.H.I. \& Lloyd, L. C. 1911. Specimens of Bushman folklore, London: George Allen. Original portrait by William Schroeder c. 1870s CE.

Figure 7: South Africa's new Coat-of-Arms with /Xam motto and centrally placed, Bushman rock painting-inspired human figures.

Word target: 5000

Word count: 5019.

Dates submitted: $13^{\text {th }}$ December 2002 and $15^{\text {th }}$ January 2003.

Dates revised: $14^{\text {th }}-25^{\text {th }}$ Dec. 2002; $11^{\text {th }}-14^{\text {th }}$ January 2003

Date accepted: 


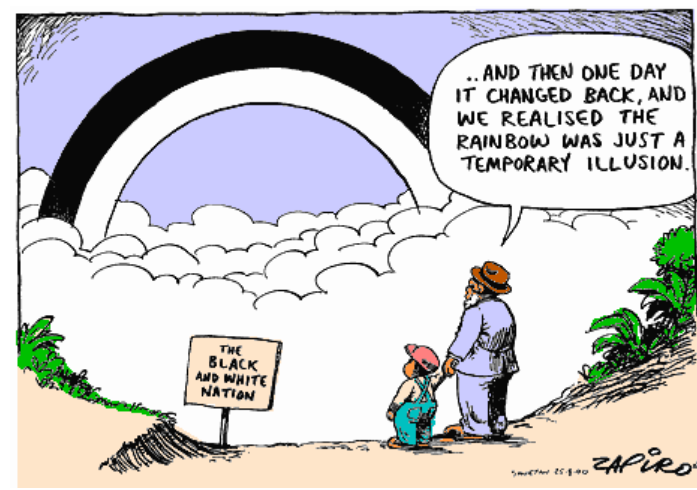

Fig. 1

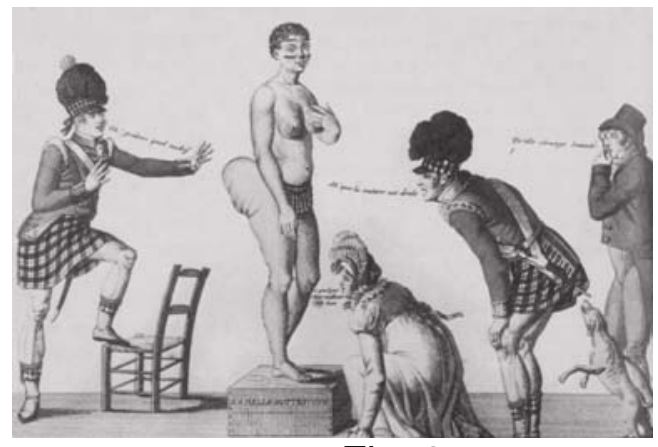

Fig. 3.

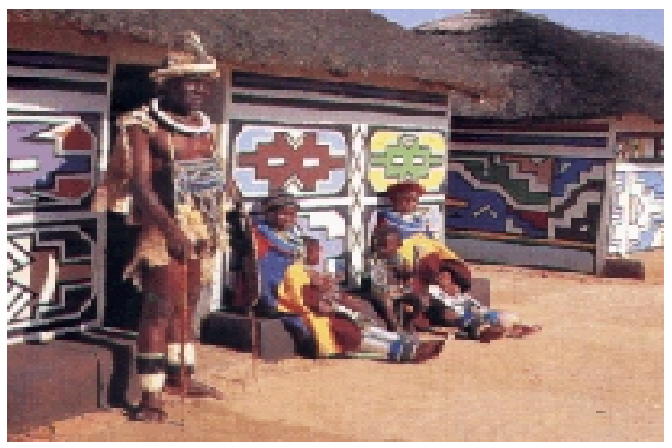

Fig. 5

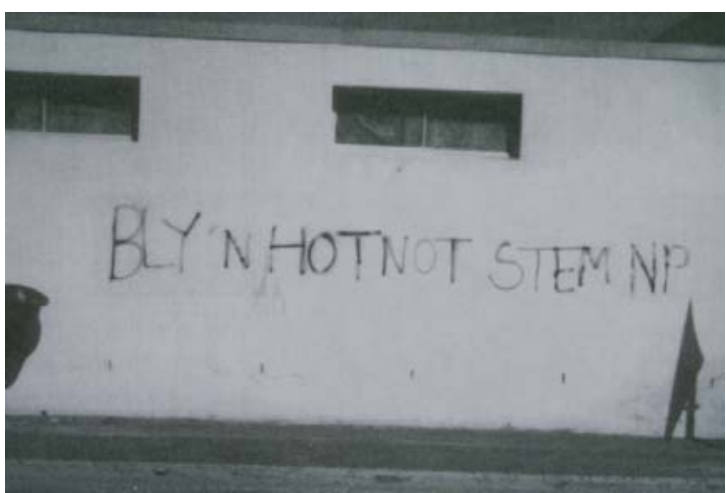

Fig. 2

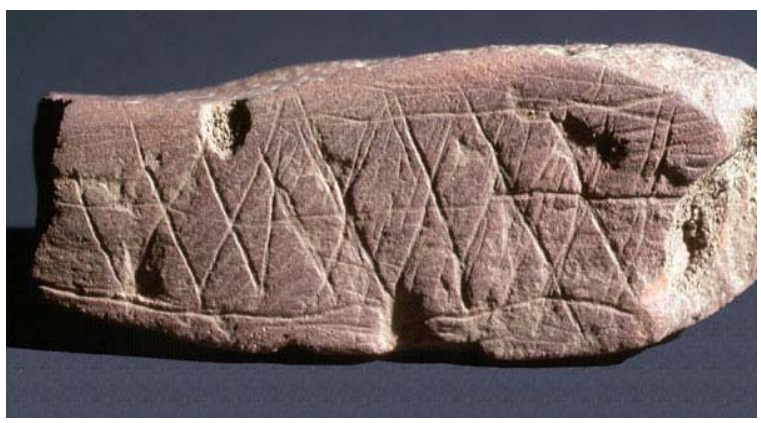

Fig 4

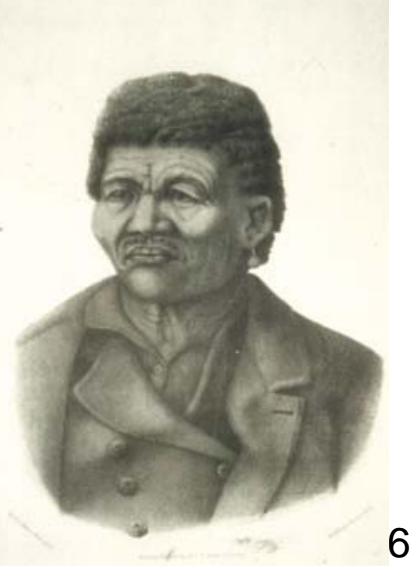

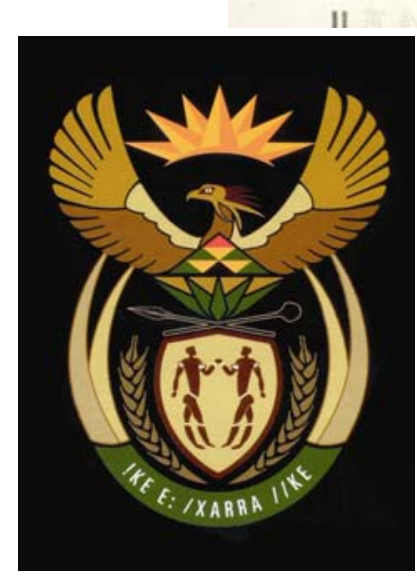


Fig. 7 